\title{
Resin Production in Natural and Artificial Red-Cockaded Woodpecker Cavity Trees
}

\author{
David L. Kulhavy1, Kimberly B. Rozelle1, William G. Ross², Daniel R. Unger', \\ Richard N. Conner ${ }^{3}$ \\ ${ }^{1}$ Arthur Temple College of Forestry and Agriculture, Stephen F. Austin State University, Nacogdoches, TX, USA \\ ${ }^{2}$ School of Forestry, Louisiana Tech University, Rustin, LA, USA \\ ${ }^{3}$ U. S. Department of Agriculture, Forest Service (Retired), Southern Research Station, Nacogdoches, TX, USA \\ Email: dkuhavy@sfasu.edu, krozelle09@gmail.com, wross@LaTech.edu, unger@sfasu.edu, \\ pcoides7@gmail.com
}

Received 20 January 2015; accepted 31 March 2015; published 3 April 2015

Copyright (C) 2015 by authors and Scientific Research Publishing Inc.

This work is licensed under the Creative Commons Attribution International License (CC BY).

http://creativecommons.org/licenses/by/4.0/

c) (i) Open Access

\begin{abstract}
Resin flow was measured in red-cockaded woodpecker (Picoides borealis Vieillot) clusters in longleaf pine (Pinus palustris Mill.) in the southern region of the Angelina National Forest, Texas. Resin flow (ml) at $1.4 \mathrm{~m}$ height over $24 \mathrm{hrs}$ was measured from one $2.5 \mathrm{~cm}$ punch through the phloem between 0700 and 1000 hrs from March 1999 to September 2000, for a total of 9 measurements per tree. Resin was sampled in naturally active cavity trees, artificial (insert) active, natural inactive, artificial inactive and control pines (84 sample trees). Resin flow pattern was significantly different during the year, but not significantly different in the cavity tree type resin flow. Cavity trees in the 90 th percentile ( $>33.0 \mathrm{ml}$ resin in $24 \mathrm{hrs}$ ) were defined as super resin producing. High average resin flows in August 1999 and September 2000 indicate when to sample resin for potential cavity trees. Regression equations were produced to estimate future resin production.
\end{abstract}

\section{Keywords}

Endangered Species, Red-Cockaded Woodpecker, Resin Sampling, Super Resin Producers, Cavity Trees

\section{Introduction}

The federally listed endangered red-cockaded woodpecker (RCW hereafter) (Picoides borealis Vieillot) (U. S. Department of Interior, 1985) is endemic to pine forests in the southeastern United States from Virginia to Florida and west to Texas (Jackson, 1971, Hooper et al., 1980; Lennartz et al., 1983; James, 1995). The RCW is a

How to cite this paper: Kulhavy, D. L., Rozelle, K. B., Ross, W. G., Unger, D. R., \& Conner, R. N. (2015). Resin Production in Natural and Artificial Red-Cockaded Woodpecker Cavity Trees. Open Journal of Forestry, 5, 364-374.

http://dx.doi.org/10.4236/ojf.2015.54031 
cooperative breeder where young males remain in their natal groups as helpers (Ligon, 1970; U. S. Department of Interior, 1985; Lennartz et al., 1987; Walters et al., 1988; Walters, 1990; Conner and Rudolph, 1995). Redcockaded woodpeckers excavate roost and nest cavities into the heartwood of living pines, generally 85 - 350 years old (Conner and Rudolph, 1991). Upon cavity completion, RCWs excavate shallow holes in the xylem, termed resin wells, and peck them daily to stimulate copious resin flow (Ligon, 1970; Dennis, 1971), to protect against predators and some nest competitors (Jackson, 1974; Jackson, 1978; Rudolph et al., 1990). Bark beetles are less successful in invading and killing southern pines with high resin flow (Lorio et al., 1990).

Artificial cavity construction (Copeyon, 1990; Copeyon et al., 1991; Taylor and Hooper, 1991) is an effective method to induce red-cockaded woodpeckers to occupy previously unoccupied habitat (Hooper et al., 1990; Watson et al., 1995). A tree characteristic not directly considered in the tree selection process for artificial cavities is the pine's resin yielding capabilities. When selecting a potential artificial cavity tree, tree diameter at cavity height (38 cm minimum), trees with larger crowns and stand location is important. Resin yield can be sampled following the methods of Lorio and Sommers (1986) and Lorio (1990). Resin production from preformed resin ducts is a primary defense against bark beetle attack (Hodges et al., 1979; Paine et al., 1985; Cook and Hain, 1986; Mitchell et al., 1991; Bowman and Huh, 1995; Coulson et al., 1995; Ross et al., 1995; Ross et al., 1997; Conner et al., 1998). Resin sampling to estimate resin from preformed resin ducts follows the methods of Lorio (1990) for measurement from 0700 - 1000 hrs. Ross et al. (1997) examined resin production in RCW longleaf pine cavity and non-cavity trees on the Angelina National forest. Bowman and Huh (1995) examined resin flow in Florida in two vegetation communities. Losses to hurricanes and bark beetles can cause loss of RCW cavity trees (Hooper et al., 1990; Conner et al., 1991; Conner et al., 1998), so both methods of evaluation for resin production for potential RCW trees and current resin status of existing cavity can assist in long term management of the species.

The objectives of this project were to evaluate resin production in longleaf pine, Pinus palustris, in redcockaded woodpecker clusters in the Angelina National Forest, Texas. Comparisons in resin production were made between natural active and inactive, and artificial natural and inactive cavity trees. Similar sizes of longleaf pines were sampled for resin as control trees.

\section{Study Area and Methods}

\subsection{Study Area}

The 61,988 ha of the Angelina National Forest $\left(31^{\circ} 15^{\prime} \mathrm{N}, 94^{\circ} 15^{\prime} \mathrm{W}\right)$, is divided by Sam Rayburn Reservoir into approximately equal areas forming the southern and northern sections. Located $45 \mathrm{~km}$ east of Lufkin, Texas, portions of the forest are in Angelina, Jasper, San Augustine and Nacogdoches counties. The study was conducted on the southern portion dominated by longleaf pine (Pinus palustris) on xeric soils of the Tehran (loamy, siliceous, thermic, Grossarenic Palendult) and Letney (loamy, siliceous, thermic, Arenic Palendult) soil series (USDA Natural Resource Conservation Service, 2010). Low water holding capacity makes regeneration difficult. The study took place in six national forest compartments: 78-1, 78-2, 88-1, 88-2, 92-1 and 92-2 located within the USDA Forest Service RCW Habitat Management Areas (HMAs). Permission to access these HMAs for study was given by the US Department of the Interior, Fish and Wildlife Service, Federal Fish and Wildlife Permit, permitted under Dr. Richard N. Conner.

Pine basal area ranged from 14 to $23 \mathrm{~m}^{2} \cdot \mathrm{ha}^{-1}$ (60 to $100 \mathrm{ft}^{2} \cdot \mathrm{acre}^{-1}$ ). The sparse midstory hardwoods include blackjack oak (Quercus marilandica) and sweetgum (Liquidambar styraciflua). The understory includes smooth sumac (Rhus glabra), bluestem (Andropogon spp.), American beautyberry (Callicarpa americana), poison ivy (Taxicodendron radicans), muscadine grape (Vitus spp.), bracken fern (Pteridiuim aquilinium) and yaupon (Ilex vomitoria).

\subsection{Status of Cavity Trees Examined}

Longleaf pines in the RCW clusters used for resin sampling were categorized according to their current activity status and method of cavity construction. The naturally excavated active cavity trees (NA) were those excavated and currently occupied by a RCW ( $\left.\mathrm{n}_{\mathrm{NA}}=13\right)$. The artificial active cavity trees (AA) contained an artificial insert and was currently occupied by a RCW $\left(n_{A A}=15\right)$. The artificial inactive cavity trees (AI) were pines with an insert that was newly constructed and either had been occupied or abandoned by a RCW $\left(\mathrm{n}_{\mathrm{AI}}=16\right)$. The natural 
inactive cavity tree (NI) was a naturally excavated tree not currently used by a RCW $\left(\mathrm{n}_{\mathrm{NI}}=16\right)$. The control tree (C) $\left(n_{c}=24\right)$ was one that had external structural characteristics similar to a cavity tree including minimum age of 60 years; height, live crown ratio (LCR) and diameter at breast height (Conner and O’Halloran, 1987) but no evidence of RCW activity, defined as resin well pecking stimulating the flow of resin. Resin flow from 83 longleaf pine (one was lost to mortality) were evaluated. There were a minimum of two control trees sampled per cluster.

\subsection{Resin Flow}

Measurements on pines in the study included diameter at breast height $(1.4 \mathrm{~m})$; total height (m); height (m) to the lowest live limb; and bole length $(\mathrm{m})$. Live crown ratio was computed as the percentage of the total height of the pine covered with living branches. Tree age was determined from past data (R. N. Conner, data on file). Rainfall for one month prior to each resin sampling event was obtained from the U. S. Department of Agriculture, Forest Service, National Forests and Grasslands in Texas, Lufkin, Texas.

\subsection{Analysis}

A repeated measures-split plot analysis of variance (ANOVA) was designed and then analyzed using SAS Version 8 software to compare means among sample trees. The ANOVA was used to test the null hypothesis of no differences among cavity-tree types with respect to resin flow, time and its effects on tree resin abilities, and the interaction of time and tree type with respect to resin flow with an alpha of 0.05 for testing. A repeated measures design was used as there are "essentially split plot designs allowing for correlation within each random effect" (Yandell, 1997).

Preliminary checks for normality and homogeneity of variances were performed prior to the ANOVA. The statistical package, JMP, was used to create distributions of resin per group (tree category $\times$ time period). Homogeneity was checked by graphing the average resin amount per group by the variance of the groups. Median resin yield instead of the mean was also graphed against time to locate outliers that hamper statistical analysis. The outliers were found above the $90^{\text {th }}$ percentile of the sample population and were considered important to the study due to high resin yields. Therefore, those trees were classified as "super resin producers" because they yielded a consistently higher amount of resin than other trees involved in the study.

A variance-stabilizing transformation was used as a step to correct heteroscedastcity of the variances. These transformations can aid in achieving the normality requirement in ANOVA. A square root transformation was used in the study because the plot of the sample averages against the sample variances resulted in a $45^{\circ}$ linear trend. This transformed data was used in the resin differences. Regression analysis was used to determine differences between slopes of each of the cavity tree types sampled for resin. The regression equations also allow for general predictions for that year's resin between sample dates for the same study trees.

\section{Results}

\subsection{Resin Production}

The distribution analysis showed a heavy skew with many outliers. The asymmetry indicated that the sample mean and the sample median did not coincide; therefore, departing from normality and suggesting the need to transform the data prior to analysis.

The statistical analysis showed no tree type effect on resin (Table 1$)(F=1.58$, df $=4, P=0.1875)$, or any effect due to an interaction of tree type and time $(\mathrm{F}=0.71$, $\mathrm{df}=32, P=0.8849)$. Although not significantly different, the artificial cavities produced resin yields with the highest mean (AA) and the lowest mean (AI) (Table 1). The control trees used in the study has a mean only slightly higher than AI cavities and slightly lower that NI, both of the inactive categories (Table 1 ). Table 2 reveals that the AA and $\mathrm{C}$ tree categories had more trees in the $90^{\text {th }}$ percentile and high resin producers in the month of August 1999. The other tree categories, NA, NI and AI each only had one tree that produced resin over $33.02 \mathrm{ml}$ (Table 2). Conversely, both active cavity tree categories, NA and AA, had the smallest number of cavity trees below the 33.02 threshold (Table 2). Therefore, there are few trees present in the lower percentiles of resin production (Table 3). There were more AI trees in the lower percentiles of resin production, while the NI was located more in the middle and the C category in the mid to upper percentiles (Table 3). 
Table 1. Descriptive statistics for twenty-four hour resin yield (ml) sampled on red-cockaded woodpecker, longleaf pine cavity trees (natural active (NA), artificial active (AA), natural inactive (NI), artificial inactive (AI), and control (C)) sampled in the southern region of the Angelina National Forest, Texas, 1999-2000. There was no significant difference among the means $(\mathrm{F}=1.58 \mathrm{df}=4, P=0.1875)$.

\begin{tabular}{cccccc}
\hline Tree Type & N & Mean Resin & Std. Dev. & Min. & Max \\
\hline NA & 13 & 10.9 & 8.2 & 0.2 & 35.5 \\
AA & 15 & 11.1 & 9.5 & 0.0 & 41.0 \\
NI & 16 & 9.0 & 7.8 & 0.0 & 34.0 \\
AI & 16 & 7.7 & 6.8 & 0.2 & 33.5 \\
C & 24 & 8.8 & 7.5 & 0.0 & 40.0 \\
\hline
\end{tabular}

Table 2. Contingency table for 24-hour resin yields (ml) for 5 tree types (natural active (NA), artificial active (AA), natural inactive (NI), artificial inactive (AI), and control (C)) of activity and construction on red-cockaded woodpecker cavities in August 1999 in the southern region of the Angelina National Forest, Texas. P-value represents the chi-square test for homogeneity.

\begin{tabular}{ccccccc}
\hline 90 $^{\text {th }}$ Percentile & NA & AA & NI & AI & C & Total \\
\hline Number of trees $>33.02$ & 1 & 3 & 1 & 1 & 2 & 8 \\
Number of trees $\leq 33.02$ & 12 & 12 & 15 & 14 & 22 & 75 \\
Totals & 13 & 15 & 16 & 15 & 24 & 83 \\
\hline
\end{tabular}

$P$-value $=0.726$.

Table 3. Number of trees in each tree category (natural active (NA), artificial active (AA), natural inactive (NI), artificial inactive (AI), and control (C)) that fall in the overall resin yield percentages during the month of August 1999, southern region of the Angelina National Forest, East Texas.

\begin{tabular}{|c|c|c|c|c|c|c|c|}
\hline \multicolumn{8}{|c|}{ Number of trees with overall resin yield (ml) } \\
\hline Tree Type & $\begin{array}{c}10 \% \text { are } \\
\text { below } 5.62\end{array}$ & $\begin{array}{c}25 \% \text { are } \\
\text { below } 9.49\end{array}$ & $\begin{array}{c}50 \% \text { are } \\
\text { below } 13.80\end{array}$ & $\begin{array}{c}75 \% \text { are } \\
\text { below } 22.40\end{array}$ & $\begin{array}{c}90 \% \text { are } \\
\text { below } 33.02\end{array}$ & $\begin{array}{c}90^{\text {th }} \\
\text { percentile }>33.02\end{array}$ & $\mathbf{N}$ \\
\hline NA & 1 & 2 & 2 & 2 & 5 & 1 & 13 \\
\hline AA & 2 & 2 & 1 & 3 & 4 & 3 & 15 \\
\hline NI & 2 & 2 & 4 & 5 & 2 & 1 & 16 \\
\hline AI & 2 & 5 & 2 & 3 & 2 & 1 & 15 \\
\hline $\mathrm{C}$ & 2 & 4 & 6 & 5 & 5 & 2 & 24 \\
\hline
\end{tabular}

The factor of time, however, did effect resin yield $(\mathrm{F}=47.46 \mathrm{df}=8, P=0.0001)$ through the sampling periods. Results indicate resin yield peaks in August and September (Table 4). It then tapers off during the late fall and through the early spring months. In both late summer measurements, the total rainfall is highest two months prior but very low one month prior to the sample date. It is during the beginning of the growing season, around April, that resin yield begins to increase again. The rainfall measurements between March and May show different trends for the two years involved. The amount of resin produced in the first year, 1999, started lower in March but peaked higher in the late summer that the year start of 2000 and last measured in September 2000 (Table 4).

A test of homogeneity of slopes using regression analysis was performed on a yearly basis. The first year, March through August 1999, showed no difference in tree types ( $F=1.924, \mathrm{df}=4,0.10<P<0.25)$, thus all year 1 regression slopes can be called statistically equal. The second year, November 1999 through September 2000, however, showed a tree type effect $(P<0.0003)$ on the resin yield of at least one tree type. The differences were found between the active trees and the inactive (including control) trees (Table 5). Those that had the same activity status showed no difference in resin yields. Table 6 is similar to a multiple comparisons for fixed 
Table 4. Eight and twenty-four hour resin flow in milliliters (ml) by date in the southern region of the Angelina National Forest, Texas. Samples taken March 1999-September 2000.

\begin{tabular}{|c|c|c|c|c|c|}
\hline \multirow{2}{*}{ Sampling Date } & \multirow{2}{*}{$\mathbf{N}$} & \multirow{2}{*}{$\begin{array}{l}\text { Eight Hours } \\
\text { Mean (SD) }\end{array}$} & \multirow{2}{*}{$\begin{array}{c}\text { Twenty-four Hours } \\
\text { Mean (SD) }\end{array}$} & \multicolumn{2}{|c|}{ Twenty-four hours } \\
\hline & & & & Min & Max \\
\hline \multicolumn{6}{|l|}{ Year 1999} \\
\hline Mar. 27 & 84 & 2.09 (2.19) & 3.38 (3.53) & 0.0 & 20.7 \\
\hline May 1 & 84 & $4.30(3.61)$ & $7.12(6.30)$ & 0.2 & 33.0 \\
\hline June 11 & 84 & $5.91(4.11)$ & 8.55 (6.18) & 0.0 & 29.0 \\
\hline Aug. 27 & 84 & 10.37 (5.11) & 16.34 (9.53) & 1.5 & 41.0 \\
\hline Nov. 12 & 84 & $3.90(3.23)$ & $6.40(5.48)$ & 0.3 & 33.2 \\
\hline \multicolumn{6}{|l|}{ Year 2000} \\
\hline Mar. 25 & 84 & $5.44(4.43)$ & $8.77(7.01)$ & 0.2 & 28.3 \\
\hline May 6 & 84 & $6.26(4.74)$ & 10.22 (7.91) & 0.0 & 32.8 \\
\hline June 7 & 84 & $5.97(4.69)$ & $10.26(8.41)$ & 0.0 & 34.0 \\
\hline Sept. 15 & $83^{*}$ & 8.47 (4.99) & 13.33 (8.54) & 0.0 & 35.0 \\
\hline
\end{tabular}

Note: Time was significantly different $(P$-value $<0.0001) .{ }^{*}$ one tree was lost to mortality.

Table 5. Regression equations for November 1999 through September 2000 resin sampling dates. Equations used to find the differences located in the slopes $\left(F_{4.15}=11.03, P<0.0003\right)$ between the resin study tree type categories of natural active (NA), artificial active (AA), natural inactive (NI), artificial inactive (AI), and control (C). Tree types that share the same underline show no significant differences in slopes. Southern region of the Angelina National Forest, East Texas, 1999-2000.

\begin{tabular}{cl}
\hline \multicolumn{1}{c}{ Regression Equation } & $\mathbf{R}^{2}$ factor \\
Tree NA $=-1.2973+0.02584$ Time & $\mathrm{R}^{2}=0.957$ \\
Tree AA $=-0.8288+0.02589$ Time & $\mathrm{R}^{2}=0.900$ \\
Tree NI $=-2.3209+0.02078$ Time & $\mathrm{R}^{2}=0.941$ \\
Tree AI $=-2.1332+0.02078$ Time & $\mathrm{R}^{2}=0.894$ \\
Time C $=-1.0556+0.01678$ Time & $\mathrm{R}^{2}=0.789$ \\
\hline
\end{tabular}

Table 6. Regression equations formulated with the 24-hour data (March 1999-August 1999) from the red-cockaded woodpecker resin-cavity (natural active (NA), artificial active (AA), natural inactive (NI), artificial inactive (AI), and control (C)) study in the southern region of the Angelina National Forest, Texas, 1999-2000. The slopes $(\mathrm{F}=1.924, \mathrm{df}=4,0.10<P<$ 0.25 from these equations can be used to estimate the gain in resin per unit of time (days).

\begin{tabular}{ll}
\hline & \multicolumn{1}{c}{ Year $\mathbf{1 9 9 9}$} \\
\hline Tree NA $=-4.9828+0.10002$ Time & $\mathrm{R}^{2}=0.995$ \\
Tree AA $=-3.2562+0.08926$ Time & $\mathrm{R}^{2}=0.956$ \\
Tree NI $=-2.9562+0.07174$ Time & $\mathrm{R}^{2}=0.993$ \\
Tree AI $=-3.1043+0.06885$ Time & $\mathrm{R}^{2}=0.995$ \\
Tree C $=-4.1836+0.08275$ Time & $\mathrm{R}^{2}=0.931$ \\
Example: What is the prediction for resin in 70 days from Year 1999, Tree NA if today's resin yield $=15 \mathrm{ml}$. \\
Slope $\times$ days $=0.10002 \times 70=7$. Prediction for 70 days from now is $15 \mathrm{ml}+7=22$ ml.
\end{tabular}

effects, but it is a coefficient of determination used for random effects (Dowdy and Wearden, 1991), such as was time in this study. Any differences in tree type could only be determined in year two (November 1999 through September 2000) but testing in the two years together reduces the effect made by year 2000 tree sample differences. 
General predictions for resin yield can be made for these study trees using the regression equations in Table 5 and Table 6. The values of $\mathrm{R}^{2}$ exceed 0.8 and was as high as 0.9 (Table 5 and Table 6). These represent a strong correlation between the actual resin values and what the linear regression model predicted. Further general inferences can be made about the covariance structure for resin yields over time.

\subsection{Super Rein Producer Analysis}

Six trees were identified as consistent outliers and were labeled super resin producers. The six trees included one from each tree type category (NA, AA, NI, AI) and two from the control (C) (Table 2, Table 7 and Table 8). Removing the super producers did little to change the results $(\mathrm{F}=1.76 \mathrm{df}=4, P=0.1414)$ for tree type effect. The quantiletest performed on the allocated super resin producers had a grand overall median of 33.02 in the $90^{\text {th }}$ percentile in August 1999 (Table 2). The special application of the chi-square test for homogeneity found strong evidence $\left(P=0.726\right.$ ) for accepting the null hypothesis that the August $199990^{\text {th }}$ percentile yields of resin were equal across all tree types (Table 3$)$. The median test resulted in no substantial evidence $(P=0.298)$ to reject the null hypothesis.

The majority of forest stand characteristics around the trees sampled differed significantly among treatments (Table 9). The diameters ( $\mathrm{F}=2.71, P=0.0359)$, live crown ratio $(\mathrm{F}=2.66, P=0.0386)$, and ages $(\mathrm{F}=7.15, P=$ $0.0045)$ of the sample trees varied among the treatments but the total height $(\mathrm{F}=0.45, P=7722)$ did not. The differences found among the tree diameters and live crown ratio existed between the naturally excavated cavity trees and the inactive naturally excavated cavity trees. The large tree spacing in the cluster areas allows most trees to obtain higher dominance class as measured by live crown ratio.

Table 7. Means for tree type categories, natural active (NA), artificial active (AA), natural inactive (NI), artificial inactive (AI), and control (C) for resin (ml) sampling dates in 1999 in the southern region of the Angelina National Forest, Texas.

\begin{tabular}{|c|c|c|c|c|c|c|}
\hline Time & Tree Type & $\mathbf{N}$ & Mean Resin & Std. Dev. & Min & Max \\
\hline \multirow[t]{5}{*}{ March 27} & NA & 13 & 3.4 & 0.2 & 0.2 & 11.0 \\
\hline & AA & 15 & 5.1 & 5.4 & 0.0 & 20.7 \\
\hline & $\mathrm{NI}$ & 16 & 3.3 & 3.2 & 0.0 & 10.4 \\
\hline & AI & 16 & 2.5 & 2.2 & 0.5 & 8.0 \\
\hline & $\mathrm{C}$ & 24 & 2.8 & 2.6 & 0.0 & 10.7 \\
\hline \multirow[t]{5}{*}{ May 1} & NA & 13 & 7.7 & 6.0 & 2.0 & 18.9 \\
\hline & AA & 15 & 8.4 & 9.1 & 1.0 & 33.0 \\
\hline & $\mathrm{NI}$ & 16 & 6.2 & 5.4 & 0.2 & 16.9 \\
\hline & AI & 16 & 5.7 & 5.0 & 0.7 & 17.2 \\
\hline & $\mathrm{C}$ & 24 & 7.5 & 5.1 & 0.3 & 23.2 \\
\hline \multirow[t]{5}{*}{ June 11} & NA & 13 & 10.6 & 5.9 & 3.0 & 18.9 \\
\hline & AA & 15 & 9.4 & 6.8 & 0.1 & 22.5 \\
\hline & $\mathrm{NI}$ & 16 & 8.2 & 6.6 & 1.0 & 26.0 \\
\hline & AI & 16 & 8.1 & 7.0 & 0.2 & 29.0 \\
\hline & $\mathrm{C}$ & 24 & 7.4 & 5.1 & 0.0 & 19.0 \\
\hline \multirow[t]{5}{*}{ Aug. 27} & NA & 13 & 19.3 & 10.3 & 3.5 & 35.5 \\
\hline & AA & 15 & 18.9 & 11.8 & 3.5 & 41.0 \\
\hline & NI & 16 & 14.5 & 9.0 & 1.5 & 34.0 \\
\hline & AI & 16 & 13.3 & 8.0 & 4.9 & 33.5 \\
\hline & $\mathrm{C}$ & 24 & 16.3 & 8.6 & 2.5 & 40.0 \\
\hline \multirow[t]{5}{*}{ Nov. 12} & NA & 13 & 6.9 & 5.9 & 0.8 & 18.6 \\
\hline & AA & 15 & 7.7 & 8.3 & 0.3 & 32.2 \\
\hline & $\mathrm{NI}$ & 16 & 6.1 & 4.9 & 0.5 & 15.5 \\
\hline & AI & 16 & 4.2 & 2.7 & 1.1 & 9.2 \\
\hline & $\mathrm{C}$ & 24 & 6.9 & 4.7 & 0.5 & 17.5 \\
\hline
\end{tabular}


Table 8. Means for tree type categories, natural active (NA), artificial active (AA), natural inactive (NI), artificial inactive (AI), and control (C) for resin (ml) sampling dates in 1999 in the southern region of the Angelina National Forest, Texas.

\begin{tabular}{|c|c|c|c|c|c|c|}
\hline Time & Tree Type & $\mathbf{N}$ & Mean Resin & Std. Dev. & Min & Max \\
\hline \multirow[t]{5}{*}{ March 25} & NA & 13 & 9.6 & 6.3 & 1.3 & 19.9 \\
\hline & AA & 15 & 9.7 & 8.6 & 0.2 & 28.3 \\
\hline & NI & 16 & 8.5 & 7.3 & 0.6 & 24.1 \\
\hline & AI & 16 & 7.8 & 7.6 & 0.9 & 26.2 \\
\hline & C & 24 & 8.5 & 6.2 & 1.5 & 21.0 \\
\hline \multirow[t]{5}{*}{ May 6} & NA & 13 & 11.9 & 6.8 & 1.2 & 22.2 \\
\hline & AA & 15 & 13.2 & 10.4 & 1.5 & 32.8 \\
\hline & NI & 16 & 10.0 & 8.2 & 0.5 & 27.0 \\
\hline & AI & 16 & 7.1 & 6.4 & 1.1 & 24.4 \\
\hline & C & 24 & 9.5 & 7.7 & 0.0 & 22.5 \\
\hline \multirow[t]{5}{*}{ June 7} & NA & 13 & 13.0 & 7.9 & 3.5 & 25.0 \\
\hline & AA & 15 & 12.0 & 10.4 & 1.4 & 34.0 \\
\hline & NI & 16 & 9.8 & 8.6 & 0.5 & 29.9 \\
\hline & AI & 16 & 9.8 & 7.6 & 1.0 & 28.0 \\
\hline & C & 24 & 8.3 & 7.7 & 0.0 & 33.1 \\
\hline \multirow[t]{5}{*}{ Sept 15} & NA & 13 & 14.4 & 9.7 & 1.5 & 31.0 \\
\hline & AA & 15 & 18.9 & 11.8 & 6.5 & 31.6 \\
\hline & NI & 16 & 14.5 & 9.0 & 1.5 & 34.0 \\
\hline & AI & 16 & 13.3 & 8.0 & 1.9 & 21.9 \\
\hline & $\mathrm{C}$ & 24 & 16.3 & 8.6 & 0.0 & 35.0 \\
\hline
\end{tabular}

Table 9. Diameter at breast height, total height, live crown ratio of longleaf sample trees by cavity type (natural active (NA), artificial active (AA), natural inactive (NI), artificial inactive (AI), and control (C)) study in the southern region of the Angelina National Forest, Texas, 1999-2000.

\begin{tabular}{cccccccc}
\hline & \multicolumn{2}{c}{ Diameter at breast height $(\mathbf{c m})$} & \multicolumn{2}{c}{ Total height $(\mathbf{m})$} & \multicolumn{2}{c}{ Live crown ratio (\%) } \\
\hline Tree Type & $\mathbf{N}$ & Mean & SD & Mean & SD & Mean & SD \\
\hline NA & 13 & $45.14^{*}$ & 7.59 & 25.41 & 6.29 & 36.99 & 13.48 \\
AA & 15 & 49.88 & 3.28 & 24.84 & 4.23 & 38.07 & 8.41 \\
NI & 16 & 51.77 & 7.87 & 23.48 & 4.84 & 40.37 & 9.46 \\
AI & 15 & 49.28 & 5.31 & 24.98 & 3.17 & 43.05 & 6.63 \\
C & 24 & $46 / 89$ & 5.41 & 24.14 & 3.84 & 46.23 & 10.28 \\
\hline
\end{tabular}

*Mean comparisons within columns significant at the alpha $=0.05$ level.

\section{Discussion}

The seasonal pattern of resin production observed coincides with that previously reported (Lorio, 1985; Conner et al., 1991; Ross et al., 1993, 1997). With the growth-differentiation balance at a low in the winter, there is little oleoresin flow from wounds while photosynthates accumulate in storage. The spring brings the start of new 
growth but little differentiation occurs because few vertical resin ducts are formed. Resin yield from wounds slowly begins during this time. The formation of summer latewood and the onset of water deficits results in differentiation that yield high resin flow. The shorter day lengths and cooler temperatures in the fall months show a halting of radial growth and a slowing of resin production and yields (Lorio, 1985). The seasonal dynamics in resin yield supports the statistical design output that there was no difference in the tree types or their interaction with time but that there was a difference in the effect of the season on resin.

With the seasonal differences (Table 4), biologists may track a tree at any time of the year to gauge its resin abilities before the decision is made for selection of potential trees for insert installation. Super rein producers occurred over the five types of sample trees indicating sampling from a homogeneous population. Depending on the limiting environmental factors, growth and differentiation processes become competitive sinks for photosynthates (Lorio, 1985). Wider spacing of trees can yield larger crowns, and faster growth until senescence is approached with tree age, and increased synthesis and flow of resin that produces conditions that favor the RCW but hinder the southern pine beetle, Dendroctonus frontalis Zimmermann, especially in longleaf pine.

Extreme moisture stress can affect the duration and quantity of resin flow decreasing the host tree defenses against bark beetles and also decreasing the success of the RCW with less resin for protection from predation by rat snakes. Adequate resin flow is affected by moisture stress reducing the flow and duration of resin (Lorio and Hodges, 1977). Droughts during the two years of this study and may be a contributing reason for less resin in 2000 (Table 4, Table 8 and Table 9).

Each tree type showed no significant statistical variance in resin flow compared to other tree types even during periods of increased resin yield. Trees selected for artificial cavity installation for use by the RCW should have a minimum threshold for resin production if these cavities are to be protected from rat snakes by an adequate rein barrier. The AI category had the lowest mean (Table 1, Table 8 and Table 9) for most sampling periods, lower than the $\mathrm{C}$ category. Conversely, the AA, artificial active trees had the highest mean (Table 1, Table 8 and Table 9) and produce more resin in the upper percentiles (Table 2 and Table 3). The active categories (NA, AA) separate from the inactive categories in the second year's spring resin yields (Table 5) with the actives holding the minimum $11 \mathrm{ml}$ amount, the highest mean in the peak resin yielding month (Table 1). Since the AA tree type mean was higher that the NA, it can be assumed that some trees chosen were very high resin producers, beneficial to the red-cockaded woodpecker. Increased observations are needed to see if high resin yields can negatively affect the RCW. The NI had a higher mean that the AI (Table 1, Table 8 and Table 9) indicating inactive natural trees can potentially produce more resin that an inactive artificial tree. In the AI category, there was one tree above the $90^{\text {th }}$ percentile, but $46 \%$ were in the $25^{\text {th }}$ percentile or below (Table 3 ).

There were droughts during the two years the study took place. The cumulative effect of two years of moisture stress related to drought may be the cause of the second year of resin measurement (Table 8 and Table 9). The same increasing trend of resin production exists from late spring to late summer during 2000, but the extent of the increase in 2000 does not reach the peaks observed in 1999 (Table 4). The start of the year 2000 resin production was higher than that of 1999 . The overall trend of resin production needs to be sampled over a longer period of time to determine resin amounts over time. With guidance from this study and Ross et al. (1997) in the same area, sampling can indicate the best resin producing longleaf pine to select for artificial cavity insertion. Strom et al. (2002) investigating loblolly pine, (Pinus taeda), promoted identifying, producing and planting high resin yielding loblolly pine as a silvicultural approach to reduce damage from the southern pine beetle.

Although longleaf pine is not the primary host of the southern pine beetle, the amount and seasonal production of resin is a deterrent against the bark beetle. Reduced resin production in RCW cavity trees may make them vulnerable to bark beetle attack (Conner et al., 2001). The presence of resin volatiles around active cavity trees may be a factor in bark beetle induced morality in active cavity trees (Conner and Rudolph, 1991; Conner et al., 1995; Hain et al., 2011). Active RCW cavity trees were more susceptible to bark beetle induced mortality than inactive cavity trees in loblolly, shortleaf (Pinus echinata) and longleaf pine (Conner and Rudolph, 1991; Conner and Rudolph, 1995; Conner et al., 1998; Hain et al., 2011). RCW breeding males selected nest cavities in trees that were heavier resin producers than cavity trees used for roosting by other group members (Conner et al., 1998). Newer cavity trees were selected for the nest cavity in longleaf pine, but the RCW did not switch to the newest artificial cavity indicating sufficient resin was available (Conner et al., 1998). Results of our study can provide times to sample and indications of higher producing resin trees. Thresholds of resin production (Table 3) indicate higher producing trees are available. For example, if $22 \mathrm{ml}$ of resin in 24 hrs in deeded adequate, then this indicates the top 25 percent of the measured trees would be potential candidates for RCW cavi- 
ties. Mean resin production is this study was $16.4 \mathrm{ml}$ in August 1999 and $13.3 \mathrm{ml}$ in September 2000 (Table 4) and can be used as a guideline for artificial cavities. The months of July, August and September are used as reference months as they are typically the peak resin yielding months (Lorio, 1985; Bowman and Huh, 1995; Ross et al., 1997). Bowman and Huh (1995) found RCWs excavate cavities in pines with maximum crown-bole ratios. Use of the regression models gives guidance to resin production (Table 5 and Table 6) over time and these can be used depending on resin measurements. RCW management is aimed at mimicking natural processes that shape the habitat for the bird.

\section{Conclusion}

Although no significant differences in resin yield were detected among cavity tree types, some pines produced more resin and were termed super producers. Pines chosen for cavity insert installation should be those pines that produce yields above the overall mean, but closer to the optimum mean of the AA and NA categories (Table 1). Any resin production by a pine that is closer to $11 \mathrm{ml}$ in the optimum resin producing months of July, August and September would have less chance for placing the RCW at risk for snake predation, or the host tree for bark beetle attack. It is not known if the RCW chooses super resin producers for nesting or roosting as super resin producers were found in each cavity tree type indicating not all super resin producers were colonized by RCW.

Mean resin production in this study was $16.34 \mathrm{ml}$ (standard deviation of 9.53) in August 1999, and $13.33 \mathrm{ml}$ (standard deviation of 4.99) in September 2000. These mean values could be used as a guideline to select the appropriate artificial cavity tree in the southern Angelina National Forest. The mean, however, will fluctuate according to moisture stress. The months of July, August and September can be used as reference months for cavity selection based on resin production. Regression equations were developed to predict resin production later in the season from early season sampling.

\section{Acknowledgements}

This project was supported by a grant from the USDA Forest Service, Southern Research Station, Nacogdoches, Texas, and McIntire Stennis funding from the Arthur Temple College of Forestry and Agriculture, Stephen F. Austin State University, Nacogdoches, Texas. Thanks are extended to Allen Smith, Carey Russell, Scott Ford, Kenny Murphy, Heather Osborne, Reagan Stephens and Scott Assenheimer for field assistance. Dr. Greg Miller, Stephen F. Austin State University, assisted with statistical analysis.

\section{References}

Bowman, R., \& Huh, C. (1995). Tree Characteristics, Resin Flow, and Heartwood Rot in Pines (Pinus palustris, Pinus elliottii), with Respect to Red-Cockaded Woodpecker Cavity Excavation, in Two Hydrologically-Distinct Florida Flatwood Communities. In D. L. Kulhavy, R. G. Hooper, \& R. Costa (Eds.), Red-cockaded Woodpecker: Recovery, Ecology and Management (pp. 415-426). Nacogdoches, Texas: Center for Applied Studies in Forestry, College of Forestry, Stephen F. Austin State University.

Conner, R. N., \& O’Halloran, K. A. (1987). Cavity Tree Selection by Red-Cockaded Woodpeckers as Related to Growth Dynamics of Southern Pines. Wilson Bulletin, 99, 398-412.

Conner, R. N., \& Rudolph, D. C. (1991). Forest Habitat Loss, Fragmentation, and Red-Cockaded Woodpecker Populations. Wilson Bulletin, 103, 446-457.

Conner, R. N., \& Rudolph, D. C. (1995). Excavation Dynamics and Use Patterns of Red-Cockaded Woodpecker Cavities: Relationships with Cooperative Breeding. In D. L. Kulhavy, R. G. Hooper, \& R. Costa (Eds.), Red-cockaded Woodpecker: Recovery, Ecology and Management (pp. 342-352). Nacogdoches, Texas: Center for Applied Studies in Forestry, College of Forestry, Stephen F. Austin State University.

Conner, R. N., Rudolph, D. C., Kulhavy, D. L., \& Snow, A. E. (1991). Causes of Mortality of Red-Cockaded Woodpecker Cavity Trees. Journal of Wildlife Management, 55, 531-537.http://dx.doi.org/10.2307/3808986

Conner, R. N., Saenz, D., Rudolph, D. C., \& Coulson, R. N. (1998). Southern Pine Beetle-Induced Mortality of Pines with Natural and Artificial Red-Cockaded Woodpecker Cavity Trees. Wilson Bulletin, 11, 100-109.

Conner, R. N., Saenz, D., Rudolph, D. C., Ross, W. G., Kulhavy, D. L., \& Coulson, R. N. (2001). Does Red-Cockaded Woodpecker Excavation of Resin Wells Increase Risk of Bark Beetle Infestation of Cavity Trees? The Auk, 118, $219-224$. http://dx.doi.org/10.2307/4089771 
Cook, S. P., \& Hain, F. P. (1986). Defensive Mechanisms of Loblolly and Shortleaf Pine against Attack by Southern Pine Beetle, Dendroctonus frontalis Zimmermann, and Its Fungal Associate, Ceratocystis minor (Hedgecock) Hunt. Journal of Chemical Ecology, 12, 1397-1406. http://dx.doi.org/10.1007/bf01012359

Copeyon, C. K. (1990). A Technique for Constructing Cavities for the Red-Cockaded Woodpecker. Wildlife Society Bulletin, 18, 303-311.

Copeyon, C. K., Walters, J. R., \& Carter III, J. H. (1991). Induction of Red-cockaded Woodpecker Group Formation by Artificial Cavity Construction. Journal of Wildlife Management, 55, 549-556. http://dx.doi.org/10.2307/3809497

Coulson, R. N., Fitzgerald, J. W., Oliveria, F. L., Conner, R. N., \& Rudolph, D. C. (1995). Red-Cockaded Woodpecker Habitat Management and Southern Pine Beetle Infestations. In D. L. Kulhavy, R. G. Hooper, \& R. Costa (Eds.), Red-Cockaded Woodpecker: Recovery, Ecology and Management (pp. 191-195). Nacogdoches, TX: Center for Applied Studies in Forestry, College of Forestry, Stephen F. Austin State University.

Dennis, J. W. (1971). Utilization of Pine Resin by the Red-Cockaded Woodpecker and Its Effectiveness in Protecting Roosting and Nest Sites. In R. L. Thompson (Ed.), The Ecology and Management of the Red-Cockaded Woodpecker (pp. 78-86). Tallahassee, FL: Bureau of Sport Fisheries and Wildlife, U. S. Department of the Interior, and Tall Timbers Research Station.

Dowdy, S. M., \& Wearden, S. (1991). Statistics for Research (2nd ed.). New York: Wiley-Interscience.

Hain, F. P., Duehl, A. J., Gardner, M. J., \& Payne, T. L. (2011). Natural History of the Southern Pine Beetle. In R. N. Coulson, \& K. D. Klepzig (Eds.), Southern Pine Beetle II (pp. 13-24). General Technical Report SRS-140, Ashville, NC: U. S. Department of Agriculture Forest Service, Southern Research Station.

Hodges, J. D., Elam, W. W., Watson, W. F., \& Nebeker, T. E. (1979). Oleoresin Characteristics and Susceptibility of Four Southern Pine Beetle (Coleoptera: Scolytidae) Attacks. The Canadian Entomologist, 111, 889-896. http://dx.doi.org/10.4039/Ent111889-8

Hooper, R. G., Robinson Jr., A. F., \& Jackson, J. (1980). The Red-Cockaded Woodpecker: Notes on Life History and Management. General Report SA-GR 9, Atlanta, GA: U. S. Department of Agriculture, Forest Service, 8 p.

Hooper, R. G., Watson, J. C., \& Escano, R. E. F. (1990). Hurricane Hugo's Initial Effects on Red-Cockaded Woodpeckers in the Francis Marion National Forest. Transactions of the North American Wildlife and Natural Resources Conference, 55, 220-224.

Jackson, J. A. (1971). The Evolution, Taxonomy, Distribution, Past Populations, and Current Status of the Red-Cockaded Woodpecker. In R. L. Thompson (Ed.), The Ecology and Management of the Red-Cockaded Woodpecker (pp. 4-29). Tallahassee, FL: Bureau of Sport Fisheries and Wildlife, U. S. Department of the Interior, and Tall Timbers Research Station.

Jackson, J. A. (1974). Gray Rat Snakes versus Red-Cockaded Woodpeckers: Predator-Prey Adaptations. The Auk, 91, 342347.

Jackson, J. A. (1978). Analysis of the Distribution and Population Status of the Red-Cockaded Woodpecker. In R. R. Odum, \& L. Landers (Eds.), Proceedings of the Rare and Endangered Wildlife Symposium (pp. 101-111). Georgia Department of Natural Resources, Game and Fish Division Technical Bulletin W44.

James, F. C. (1995). The Status of the Red-Cockaded Woodpecker in 1990 and the Prospect for Recovery. In D. L. Kulhavy, R. G. Hooper, \& R. Costa (Eds.), Red-Cockaded Woodpecker: Recovery, Ecology and Management (pp. 436-438). Nacogdoches, TX: Center for Applied Studies in Forestry, College of Forestry, Stephen F. Austin State University.

Lennartz, M. R., Hooper, R. G., \& Harlow, R. F. (1987). Sociality and Cooperative Breeding of Red-Cockaded Woodpeckers (Picoides borealis). Behavioral Ecology and Sociobiology, 20, 77-88. http://dx.doi.org/10.1007/BF00572629

Lennartz, M. R., Geisler, P. H., Harlow, R. F., Long, R. C., Chitwood, K. M., \& Jackson, J. A. (1983). Status of the Red-Cockaded Woodpecker on Federal Lands in the South. In D. A. Wood (Ed.), Proceedings of the Red-Cockaded Woodpecker Symposium II (pp. 7-12). Tallahassee, FL: State of Florida Game and Freshwater Fish Commission.

Ligon, J. D. (1970). Behavior and Breeding Biology of the Red-Cockaded Woodpecker. The Auk, 87, 255-278. http://dx.doi.org/10.2307/4083919

Lorio Jr., P. L. (1985). Growth-Differentiation Balance: A Basis for Understanding Southern Pine Beetle-Tree Interactions. Forest Ecology and Management, 14, 259-273. http://dx.doi.org/10.1016/0378-1127(86)90172-6

Lorio Jr., P. L., \& Sommers, R. A. (1986). Evidence of Competition for Photosynthates between Growth Processes and Oleoresin Synthesis in Pinus taeda L. Tree Physiology, 2, 301-306. http://dx.doi.org/10.1093/treephys/2.1-2-3.301

Lorio, P. L., \& Hodges, J. D. (1977). Tree Water Status Affects Induced Southern Pine Beetle Attack and Brood Production. U. S. Department of Agriculture, Forest Service, Southern Forest Experiment Station, Research Paper SO-135, 7 p.

Lorio Jr., P. L., Sommers, R. A., Blanche, C. A., Hodges, J. D., \& Nebeker, T. E. (1990). Modeling Pine Resistance to Bark Beetles Based on Growth and Differentiation Balance Principles. In R. K. Dixon, R. S. Meldaho, G. A. Ruark, \& W. G. Warren (Eds.), Process Modeling of Forest Growth Responses to Environmental Stress (pp. 402-409). Portland, OR: Timber Press. 
Mitchell, J. H., Kulhavy, D. L., Conner, R. N., \& Bryant, C. M. (1991). Susceptibility of Red-Cockaded Woodpecker Colony Areas to Southern Pine Beetle Infestations in East Texas. Southern Journal of Applied Forestry, 15, 158-162.

Paine, T. D., Stephen, F. M., \& Cates, R. G. (1985). Induced Defenses against Dendroctonus frontalis and Associated Fungi: Variation in Loblolly Pine Resistance. In S. J. Branham, \& R. C. Thatcher (Eds.), Proceedings of the Integrated Pest Management Research Symposium: The Proceedings (pp. 167-169). U. S. Department of Agriculture, Forest Service, General Technical Report SO-56.

Ross, W. G., Kulhavy, D. L., \& Conner, R. N. (1993). Evaluating Susceptibility of Red-Cockaded Woodpecker Cavity Trees to Southern Pine Beetle in Texas. In C. Brissette (Ed.), Proceedings of the Seventh Biennial Southern Silvicultural Work Conference, Mobile, Alabama (pp. 547-553). New Orleans, LA: Southern Forest Experiment Station, General Technical Report SO-93, U. S. Department of Agriculture, Forest Service.

Ross, W. D., Kulhavy, D. L., \& Conner, R. N. (1995). Vulnerability and Resistance of Red-Cockaded Woodpecker Cavity Trees to Southern Pine Beetle in Texas. In D. L. Kulhavy, R. G. Hooper, \& R. Costa (Eds.), Red-Cockaded Woodpecker: Recovery, Ecology and Management (pp. 401-414). Nacogdoches, TX: Center for Applied Studies in Forestry, College of Forestry, Stephen F. Austin State University.

Ross, W. G., Kulhavy, D. L., \& Conner, R. N. (1997). Stand Conditions and Tree Characteristics Affect Quality of Longleaf Pine for Red-Cockaded Woodpecker Cavity Trees. Forest Ecology and Management, 1, 145-154. http://dx.doi.org/10.1016/S0378-1127(96)03894-7

Rudolph, D. C., Kyle, H., \& Conner, R. N. (1990). Red-Cockaded Woodpeckers versus Rat Snakes: The Effectiveness of the Resin Barrier. Wilson Bulletin, 102, 14-22.

Taylor, W. E., \& Hooper, R. G. (1991). A Modification of Copeyon's Drilling Technique for Making Artificial Red-Cockaded Woodpecker Cavities. General Technical Report SE-72, Asheville, NC: Southeastern Forest Experiment Station, U. S. Department of Agriculture Forest Service.

Strom, B. A., Goyer, R. A., Ingram, L. L., Boyd, G. D. L., \& Lott, L. H. (2002). Oleoresin Characteristics of Progeny of Loblolly Pines That Escaped Attack by the Southern Pine Beetle. Forest Ecology and Management, 158, 169-178. http://dx.doi.org/10.1016/S0378-1127(00)00710-6

U. S. Department of Interior, Fish and Wildlife Service (1985). Red-Cockaded Woodpecker Recovery Plan. Atlanta, GA: U. S. Fish and Wildlife Service, 88 p.

U. S. Department of Agriculture, Natural Resource Conservation Service (2010). Soil Survey of San Augustine and Sabine Counties, Texas. U. S. Department of Agriculture, Natural Resources Conservation Service, 654 p.

Walters, J. R. (1990). Red-Cockaded Woodpecker, Picoides borealis borealis. Occasional Paper, North Carolina Biological Survey, 20-23.

Walters, J. R., Doerr, P. D., \& Carter III, J. H. (1988). The Cooperative Breeding System of the Red-Cockaded Woodpecker. Ethology, 78, 275-305. http://dx.doi.org/10.1111/j.1439-0310.1988.tb00239.x

Watson, J. C., Carlson, D. L., Taylor, W. E., \& Milling, T. E. (1995). Restoration of the Red-Cockaded Woodpecker Population on the Francis Marion National Forest: Three Years Post Hugo. In D. L. Kulhavy, R. G. Hooper, \& R. Costa (Eds.), Red-Cockaded Woodpecker: Recovery, Ecology and Management (pp. 172-182). Nacogdoches, TX: Center for Applied Studies in Forestry, College of Forestry, Stephen F. Austin State University.

Yandell, B. S. (1997). Practical Data Analysis for Designed Experiments. Madras: Chapman and Hall, 312 p. http://dx.doi.org/10.1007/978-1-4899-3035-4 